\title{
A European Mechanism for the Issuance and Initial Distribution of Debt Securities
}

\begin{abstract}
Although the European Union (EU) has implemented initiatives and common rules regarding securities settlements, no similar integration initiatives have been proposed for the issuance and initial distribution of debt securities. The EU does not function as a single market given that issuers of euro debt instruments still have to use multiple and non-harmonised channels and procedures. A harmonised European framework for the issuance and initial distribution of debt securities or the establishment of a new European market infrastructure service is widely considered a way to create a deep and liquid single market for debt instruments. While such a paradigm shift promises significant improvements compared with the existing debt issuance and distribution landscape, a hasty and poorly designed public intervention would risk distorting the market, thereby increasing complexity and bringing more fragmentation.
\end{abstract}

In May 2019, the Eurosystem launched a public consultation and invited relevant market participants to provide their views on the establishment of a European mechanism for the issuance and initial distribution of debt securities in the European Union (European Central Bank [ECB], 2019b). Establishing such a mechanism would have an impact not just on issuers and investors, but also on the central securities depositories (CSDs), custodians, dealers, issuing agents, paying agents and other stakeholders who would have to learn how to work with the new mechanism.

In the aftermath of the recent global financial crisis, the EU has accelerated efforts to establish a single integrated capital market (European Commission [EC], 2015). An important component thereof is the market for debt securities, which has almost tripled in the last 20 years in terms of outstanding amounts of debt - $€ 17,382$ billion in 2019 compared with $€ 6,458$ billion in 1999 (ECB, 2020). Nevertheless, since 2001, the EU has identified several problems and restrictions on the activities of primary dealers of debt instruments, resulting in market-makers often having to set up local securities

(C) The Author(s) 2020. Open Access: This article is distributed under the terms of the Creative Commons Attribution 4.0 International License (https://creativecommons.org/licenses/by/4.0/).

Open Access funding provided by ZBW - Leibniz Information Centre for Economics.

Georgios Pavlidis, Neapolis University of Pafos, Cyprus. operations and using the local settlement system for settling transactions (EC, 2003). The location of the financial instruments and that of the parties involved in a financial transaction continue to affect issuance, trading, clearing and settlement procedures. Integrating national financial markets at the EU level would require breaking this link.

Thus far, the EU has implemented initiatives and common rules regarding securities settlements. For example, the 2014 regulation on central securities depositories (CSD Regulation; Regulation (EU) 909/2014, 2014) lays out applicable rules and requirements for CSDs operating securities settlement systems. Another example is the establishment of the TARGET2-Securities (T2S), a platform for securities settlements allowing for the safe and simultaneous payment and delivery of securities (ECB, 2019c; ECB, 2018). However, in the context of the issuance and initial distribution of debt securities, no similar integration initiatives have been proposed. Therefore, the EU does not function as a single market in this regard and issuers of euro debt instruments still have to resort to multiple, non-harmonised channels and procedures.

Issuance process for debt securities: Weaknesses and challenges

Currently, the pre-issuance phase involves the preparation of the debt issuance and price discovery and takes place through syndication, auctioning or private placement, depending on the issuer's choice (European Post Trade Forum, 2017). Dealer banks and agents provide advice to the issuer and underwrite the issuance; these dealers also interact with investors and collect orders following applicable regulatory 
considerations, such as the know-your-customer (KYC) requirements (Association for Financial Markets in Europe [AFME], 2019). Dealer banks may provide the proprietary tools necessary to support these activities, although technical facilities provided by a third party can be used as well. At the end of this process, the issuer and the investors conclude an agreement on the economic terms of the securities and the trade is finalised.

Meanwhile, in the post-trade phase, debt securities are issued in CSDs and are delivered to investors (Wendt et al., 2018). The distribution of debt securities to investors takes place through intermediaries and multiple distribution channels (AFME, 2015; SWIFT, 2017). In fact, the distribution of a new issue is "a very first, short step before secondary market operations start" (European Central Securities Depositaries Association, 2019). In the lifespan of the debt security, agent banks represent the issuers in terms of the management of securities and cash accounts; that is, they collect and distribute interest payments to investors who hold final balances with CSDs, local custodians or global custodians.

The main weakness of the existing securities distribution channels, however, is the fact that they remain fragmented and largely national. Given the variations in national regulations and procedures for issuing and holding debt securities (Deutsche Bank [DB], 2019), investors may face unnecessary costs and complexity. Whereas issuers, for their part, are prevented from efficiently reaching all investors on an equal basis, especially when small debt issues are involved. Evidently, this should not be the case in a single capital market.

Furthermore, due to the lack of a pan-European issuance mechanism, issuers are very likely to choose their domestic market and local CSD. Thus, market participants located at the country of issuance might find themselves in a preferential position. Under the current fragmented regime, local investors are facing a smaller number of intermediaries and lower costs of holding assets compared with foreign investors (Goldberg, 2002). Such a privileged position in terms of issuance location and local participants prevents the entry of other investors - a situation that is incompatible with a single capital market.

Finally, the lack of efficiency by which debt securities are issued in the EU is aggravated by the insufficient interoperability and the low level of digitalisation among the existing multiple issuance platforms (Callsen, 2018). This 'structural gap' renders the issuance and distribution channels in the EU less competitive than those in other jurisdictions, such as the United States and Japan (ECB, 2019a). A pan-European system could address this gap, significantly improve competition and level the playing field among issuers, investors and other market participants.
Towards a harmonised system for the issuance of debt securities

Harmonisation could be an avenue for creating a deep and liquid single market for debt instruments in the EU. Contrary to the post-trade phase, where some progress has been made in regulatory harmonisation (e.g. MiFID II, EMIR, CSD Regulation, T2S; Directive 2014/65/EU, 2014; Regulation (EU) 648/2012, 2012), no harmonisation initiatives have been implemented in the pre-issuance phase.

A new European secondary law instrument on the issuance and initial distribution of debt securities could promote standardisation and heighten connectivity between platforms, thus improving the access of market participants to debt securities. Obviously, such a harmonised European framework should be based on the principle of neutrality, which ensures that "the desired market structure is such that it does not put the location of issuance (i.e. of the issuer CSD and its direct participants) in a privileged position over other intermediaries and end users that wish to access the securities" (ECB, 2019a).

Standardisation and harmonisation could cover, among other topics, rounding conventions, aligning definitions, in particular standardising terminology (Deutsche Börse Group, 2005), but also harmonising and standardising of processes, including the auction process, order transmission and the order book. To avoid legal uncertainty and inconsistencies, standardisation and harmonisation should cover both ends of the transaction chain, from pre-issuance to post-trade.

\section{Establishing a European market infrastructure service}

The establishment of a new European market infrastructure service is another method for creating a deep and liquid single market for debt instruments. A new central service would allow for a single pre-issuance and an initial distribution process as well as ensure a level playing field for euro debt issuers, investors and other market participants, thus facilitating the establishment of a genuine single market. The establishment of a European market infrastructure should not serve as a substitute for harmonisation; rather, the two initiatives could be combined in such a way that they complement each other.

For the establishment of a European market infrastructure, the involved parties should either adopt or endorse a multilateral arrangement. A practical question is whether this infrastructure should be offered by a private or a public entity and what the role of the European Central Bank (ECB) would be in this context. In our view, the operation of the services should be commercially run by the private sector, although 
some form of public-private cooperation could be useful in the initial stages of the project, where sponsorship by the public sector would be helpful.

Two components of a European Distribution of Debt Instruments

Under the 2019 Eurosystem proposal for a European Distribution of Debt Instruments (EDDI), a European market infrastructure service could have two components on the basis of a modular, optional and voluntary approach that would allow users to choose whether they want to use both components, one of them or none at all.

The first component of the proposed new service would be a technical toolkit for the pre-issuance phase which would allow "the communication of an upcoming debt issue, the creation of the order book, the collection of orders from investors and the allocation of the debt instrument issuance to these orders" (ECB, 2019a). These functionalities can be automated and made available to issuers, issuer agents and/ or dealer banks, although there will still be interactions (e.g. negotiation, consultation, advice) that, by their nature, cannot be part of an automated process. Furthermore, a 'multicurrency functionality' must be developed as it would allow EDDI to become a 'one-stop shop' for borrowers that issue debt both in euro and other currencies.

The second component would offer functionalities for the post-trade phase of debt securities. In particular, it would receive the final allocation from the previous phase and then distribute the newly issued debt instruments via collaborating CSDs connected to the system. Notary service could also be provided, particularly regarding the integrity of the issuance's global amount. For the life cycle of the securities, the post-trade component would support information flows and interest payments and enable secondary market transactions involving different CSDs. Synergies with CSDs could be developed within the framework of the TARGET services, including the T2S auto-collateralisation function (Clearstream, 2017).

The use of the new system should remain optional and not mandatory, that is, the market participants should be given the opportunity to decide whether EDDI's advantages weigh in favour of its use and provide value for money. The two aforementioned modules could be introduced in two separate stages, beginning with the post-trade platform that already enjoys support from market participants (International Capital Market Services Association, 2019). In any event, the functioning of the single financial market requires that access to the new system should not be restricted to certain categories of issuers (e.g. supranational, sovereign, sub-sovereign issuers) nor to certain CSDs.

\section{Advantages of a new European infrastructure service}

Through the proposed EDDI, the market participants will have access to a single, central platform that offers the advantages of neutrality and standardisation. Therefore, the new European infrastructure service would facilitate interactions within markets.

From the issuers' point of view, the EDDI service would enable them to issue debt instruments that can reach investors in the entire EU, without having to choose a specific location of issuance. Thus, due to its pan-European reach, the new service could increase the liquidity of the issued securities and the geographical diversification of the investor base (Committee on the Global Financial System, 2019). Ultimately, the new service can help promote the efficiency and attractiveness of the issuance of euro debt securities.

From the investors' point of view, the proposed EDDI service would offer a single and standardised communication channel for all instruments offered through it; it would facilitate interactions and information flows between investors and issuers. This would constitute a significant improvement compared with the multiple, non-standardised channels and interfaces that are currently available.

From the custodians' point of view, the EDDI service would facilitate interactions within the custody chain (Chan et al., 2007; International Securities Services Association, 2017). Under the proposed framework, the main criteria for choosing a CSD will be the level of the service and the cost and not the location of issuance. Custodians will no longer have to use a multiplicity of CSDs for European issuances (DB, 2019), and for this reason, the EDDI would help them optimise the custody of debt instrument holdings.

\section{Potential areas of conflict}

The 2019 Eurosystem proposal makes clear that EDDI does not aim to compete with existing intermediaries (agents, dealer banks, custodians, etc.) or force a disintermediation. Intermediaries could resort to EDDI services, opting to use both, one or none of its modules; they do not need to abandon their own proprietary procedures. Nevertheless, this would require two things: on the one hand, an EDDI preissuance component should be designed to support posttrade outside EDDI; on the other hand, an EDDI post-trade component should be designed in such a way that it allows connectivity and linking with private pre-issuance platforms - whether existing or newly established.

We argue that EDDI should not distort completion nor discourage the development of alternative market solutions. However, it must be admitted that, even if EDDI is designed 
to be voluntary, the risk that it would gain a dominating position remains, especially if it is set up as an official sector facility, given that market participants will be under pressure to prefer it over other alternatives.

In any case, EDDI will change the way market participants operate, in particular CSDs. If securities are issued through EDDI, the CSD's ranking in the custody chain will no longer be so relevant, i.e. whether the CSD acts as 'issuer' or 'investor' for the issuance in question. Therefore, on the downside, the CSD will sacrifice exclusivity over the primary deposit as established by the location of issuance. The upside, however, is that the CSD will gain access to numerous securities issued through EDDI on an equal basis, thus creating a level playing field with no location exclusivities.

Finally, if the ECB is involved in the operation of the EDDI platform, concerns about potential conflicts of interests must be addressed as the ECB's holdings include euro area bonds as well as sovereign and corporate asset backed securities. Similarly justified concerns were raised over the International Monetary Fund's dual role as creditor and host of a dispute settlement forum in the context of the 2001 proposal for a Sovereign Debt Restructuring Mechanism (SDRM), a project that was later abandoned (Krueger, 2002; International Monetary Fund, 2002). In our view, the ECB should not be involved at all in the operation of EDDI or, at the very least, stringent safeguards should be introduced so that the ECB does not gain an information advantage over other market participants.

\section{EDDI to drive transparency and harmonisation}

The issuance of debt in euro would be considerably improved by the establishment of a pan-European system. As the Managing Director of the European Stability Mechanism has correctly pointed out, "a single system to distribute sovereign bonds would offer investors - especially international investors - more transparency and ease access for them" (Regling, 2018). In the United States, a single system is in place with the New York Fed acting as the fiscal agent of the federal government, conducting auctions and performing auction-related settlements (Federal Reserve Bank of New York, 2019). Establishing EU rules on the issuance and initial distribution of debt securities could eventually lead to a single system for sovereign and sub-sovereign bond auctions, following the US model. Such an initiative can also foster harmonisation in other fields, such as sovereign bond terms and conditions.

In our view, the establishment of EDDI would constitute an important development towards the Capital Market Union. As EDDI would adopt a modular, voluntary and optional approach, market participants may continue to use existing is- suance and distribution channels outside EDDI, depending on the issuer's strategies. In this case, market participants should "in principle benefit from the positive externalities of the EDDI harmonisation agenda" (ECB, 2019a).

\section{Inclusion of market participants to ensure support for EDDI}

Despite the advantages, however, two more issues need to be addressed in EDDI's design. Firstly, the market participants should be involved in the future governance of EDDI to ensure that the costs for users will be acceptable and kept under control. Secondly, EDDl's design should address market concerns about "access [...] to confidential data regarding investors and their relevant trading activity" (International Capital Market Association, 2019).

Harmonisation initiatives and pan-European projects, such as the proposed EDDI, are often attractive in theory and give rise to interesting debates at the academic and policy levels; however, they are difficult to implement in practice and are met with scepticism by the actual market participants (International Capital Market Services Association, 2019). The establishment of an EDDI promises significant improvements compared to the existing debt issuance and distribution landscape; nevertheless, a hasty and poorly designed public intervention would risk distorting the market, thereby increasing complexity and leading to more fragmentation (European Central Securities Depositaries Association, 2019). For this reason, the detailed design and actual implementation of the new system must consider and subsequently address the concerns of market participants. In doing so, the new system may gain support from and consensus amongst the largest possible spectrum of stakeholders who will be called to work with the new system.

\section{References}

Association for Financial Markets in Europe (2015), Post Trade Explained: The Role of Post-Trade Services in the Financial Sector.

Association for Financial Markets in Europe (2019), AFME response to the ECB market consultation on a potential mechanism for the issuance and initial distribution of debt securities in the European Union (EDDl).

Braeckevelt, F. (2006), Clearing, settlement and depository issues, in Bank for International Settlements, Asian bond markets: issues and prospects, BIS Papers, 30.

Callsen, G. (2018), Electronification in Primary Bond Markets, Quarterly Report, International Capital Market Association, 50(third quarter), 26-27.

Chan, D., F. Fontan, S. Rosati and D. Russo (2007), The Securities Custody Industry, ECB Occasional Paper, 68.

Clearstream (2017), The Future of Global Debt Issuance, 2025 Outlook.

Committee on the Global Financial System (2019), Establishing Viable Capital Markets, Bank for International Settlements, CGFS Papers, 62.

Deutsche Bank (2019), Transitioning into the future of securities post-trade, White Paper.

Deutsche Börse Group (2005), The European Post-Trade Market: An Introduction, White Paper. 
Directive 2014/65/EU of the European Parliament and of the Council of 15 May 2014 on markets in financial instruments (MiFID II), Official Journal of the European Union, L173, 349-496.

European Central Bank (2018), T2S: One year of full operation, T2S Special Series, 7.

European Central Bank (2019a), Market consultation on a potential Eurosystem initiative regarding a European mechanism for the issuance and initial distribution of debt securities in the European Union, https://www.ecb.europa. eu/paym/pdf/consultations/market_consultation_on_european_distribution_of_debt_securities.en.pdf (15 March 2020).

European Central Bank (2019b), Public consultations, https://www.ecb.europa.eu/paym/cons/html/index.en.html (10 March 2020).

European Central Bank (2019c), What is TARGET2-Securities (T2S)?, https:// www.ecb.europa.eu/paym/target/t2s/html/index.en.html (15 March 2020).

European Central Bank (2020), Statistical Data Warehouse, Debt securities, http://sdw.ecb.int/browse.do?node=9691433 (14 March 2020).

European Central Securities Depositaries Association (2019), ECSDA Response to ECB market consultation related to EDDI.

European Commission (2001), Cross-border Clearing and Settlement Arrangements in the European Union, First Giovannini Report, https://ec.europa. eu/info/publications/giovannini-reports_en (14 March 2020).

European Commission (2003), EU Clearing and Settlement Arrangements, Second Giovannini Report, https://ec.europa.eu/info/publications/giovannini-reports_en (14 March 2020).

European Commission (2015), Action Plan on Building a Capital Markets Union, $\operatorname{COM}(2015) 468$ final, https://ec.europa.eu/transparency/regdoc/ rep/1/2015/EN/1-2015-468-EN-F1-1.PDF (13 March 2020).

European Commission (2017), Communication on the mid-term review of the capital markets union action plan, COM(2017) 292 final, https://ec.europa. eu/info/sites/info/files/communication-cmu-mid-term-review-june2017_ en.pdf (13 March 2020)

European Post Trade Forum (2017), EPTF Report, Annex 3, https://ec.europa. eu/info/sites/info/files/170515-eptf-report-annex-3_en.pdf (15 March 2020).

Federal Reserve Bank of New York (2019), Treasury Debt Auctions and Buybacks as Fiscal Agent, https://www.newyorkfed.org/markets/treasurydebt-auctions-and-buybacks-as-fiscal-agent.

Goldberg, L., J. Kambhu, J. M. Mahoney, L. Radecki and A. Sarkar (2002), Securities Trading and Settlement in Europe: Issues and Outlook, Federal Reserve Bank of New York, Current Issues in Economics and Finance, 8(4).

International Capital Market Association (2019), EDDI - Market consultation on a potential Eurosystem initiative regarding a European mechanism for the issuance and initial distribution of debt securities in the European Union.

International Capital Market Services Association (2019), Response to Market consultation on a potential Eurosystem initiative regarding a European mechanism for the issuance and initial distribution of debt securities in the European Union.

International Monetary Fund (2002), IMF Board Discusses Possible Features of a New Sovereign Debt Restructuring Mechanism, IMF Public Information Notice.

International Securities Services Association (2017), Inherent Risks within the Global Custody Chain.

Krueger, A. (2002), A New Approach to Sovereign Debt Restructuring, International Monetary Fund.

Regling, K. (2018), The future of the Economic and Monetary Union and the role of the ESM, https://www.esm.europa.eu/speeches-and-presentations/ future-economic-and-monetary-union-and-role-esm-speech-klausregling (15 March 2020).

Regulation (EU) 909/2014 of the European Parliament and of the Council of 23 July 2014 on improving securities settlement in the European Union and on central securities depositories and amending Directives 98/26/EC and 2014/65/EU and Regulation (EU) No. 236/2012, Official Journal of the European Union, L257, 1-72.

Regulation (EU) 648/2012 of the European Parliament and of the Council of 4 July 2012 on OTC derivatives, central counterparties and trade repositories (European market infrastructure regulation - EMIR), Official Journal of the European Union, L201, 1-59.

SWIFT (2017), Rewiring securities post-trade: Challenges and opportunities in the new order, White Paper.

Wendt, F., P. Katz and A. Zanza (2018), Organizing Central Securities Depositories in Developing Markets: 7 Considerations, IMF Working Paper, WP/18/66. 